\title{
Extension Strategies to Popularisation of Multicut Fodder Sorghum var. COFS-31 in Chitradurga District, Karnataka State, India
}

\author{
Rudragouda F. Channagouda*, S. Onkarappa, Prakash Kerure, \\ Jyoti and T. Rudramuni
}
Krishi Vigyan Kendra, Babbur Farm, Hiriyur (Taluk), Chitradurga (District), Karnataka (State) University of Agricultural and Horticultural Sciences, Shivamoga, Karnataka *Corresponding author

\section{Ke y w ords \\ Multicut Fodder Sorghum, COFS-31 \\ Article Info \\ Accepted: \\ 04 October 2020 \\ Available Online: \\ 10 November 2020}

\section{A B S T R A C T}

The demonstrations were conducted in chitradurga district during 2017-18 and 2018-19 to study on "Extension strategies to popularisation of multicut fodder sorghum var. COFS-31 in Chitradurga district, Karnataka state, India". These studies were comprised two plots as demo and check plot and demonstrated in 250 farmer's field. Success stories or technology act as a catalyst in making institution more vibrant, work oriented and people friendly. They infuse a new life in the work culture of KVK and make them more responsive to the needs of farmers. KVK Chitradurga has its own share of technologies identified and methodologies adopted. During the first year, only five farmers were grown the new fodder sorghum variety COFS-31 variety. After the continuous efforts, enthusiasm and dedication of KVK scientists it spread around 1250 farmers of the district with tune of 12.8 per cent adoption in the district within two years. To create awareness on this variety through conducted twelve on and off campus training programmes during implementation period. Among the two fodder varieties, fodder sorghum variety COFS-31 produced higher stem height $(210.6 \mathrm{~cm})$, leaf width $(4.5 \mathrm{~cm})$ and green fodder yield $(89.6 \mathrm{t} / \mathrm{ha})$ and lower stem girth $(3.2 \mathrm{~cm})$ over Napier hybrid bajra $(210.6,4.1,5.4$ and $74.7 \mathrm{t} / \mathrm{ha}$, respectively) which is higher by 19.9 per cent. The higher palatability per cent was recorded in COFS -31 $(90.4 \%)$ over Napier hybrid bajra $(81.8 \%)$ with tune of 11.5 per cent. The income before and after adaption of this technology were Rs. 17794 /ha and 23215, respectively.

\section{Introduction}

Success of any technology is the essence of any institution in general and KVK in particular. It depicts the magnitude of work culture. The edifice of income generating activities followed up with field level demonstrations, transfer of technology skills, conducting of front line demonstration, trainings and other related activities of a $\mathrm{KVK}$ stand as a corner stone on which $\mathrm{KVK}$ is built. In fact, a KVK without technology is as a human being drained off blood. Success stories or technology act as a catalyst in making institution more vibrant, work oriented and people friendly. They infuse a new life in the work culture of KVK and make them more responsive to the needs of 
farmers. KVK Chitradurga has its own share of technologies identified and methodologies adopted.

India has large livestock population in the world. The livestock population has been expanding and changing in response to changes in technological, economic and institutional spheres. The livestock population has been increased significantly from 353.6 million in 1972 to 470.86 million in 1992 and then to 529.7 million in 2007.Crop economy continues to be a dominant sector contributing about three fourth of total agricultural income. Although animal husbandry and dairying are considered supplementary to crop production, they play important roles in the agricultural economy. It is argued that the recent high growth in agricultural sector is mainly contributed by a respectable growth from the livestock sector. In fact, share of livestock in value of agricultural output has increased substantially from 18.0 per cent in $1970-71$ to 20.0 per cent in $1980-81,24.0$ per cent in 1990-91 and then to 27.0 per cent in 2007-08 respectively.

Chitradurga district come under central dry zone of Karnataka and receives less and uneven distribution rainfall throughout the year. In this region, dairy is one of the important alternative components for economic security of the farmers. Total live stock population of (Anon., 2016). Chitradugra are 18,47,000 (341000 cattle, 193000 buffalo, 369000 goat and 931000 sheep's, respectively) During the last few years, farmers of Chitradurga suffering from the frequent drought seasons which had a large negative impact on dairy farmers. This is severely threatening the availability of fodder for the dairy animals and leads to shortage of $8 \mathrm{Mt}$ fodder. The problem analysis revealed that the lower yields in this region mainly due to lack of technical knowledge on use of drought resistant, high palatability and fodder yielding varieties, fodder production technology, farmers grown fodder crops on marginal land and rainfed situation. Thus front line demonstrations, method demonstration, trainings, news paper and radio were planned to create awareness about the technology and improve the yields of fodder in the district.

The introduction of new variety COFS-31, combined use of organic manures, biofertilizers, macro and micronutrient would go a long way in maximizing fodder production per unit area.

In this background, we have planned to conduct the large scale demonstrations on Introduction multicut fodder variety COFS for higher yield in Chitradurga district.

\section{Characters of COFS-31}

High yielding and quick growing

Drought resistant

Perennial with multi cut green fodder

First cut is taken after two months sowing and subsequent cuts can be taken at the intervals of 50-60 days

High palatability and thin stem

\section{Preamble}

Drought resistant crop of Chitradurga dist.

Mainly cultivated under low fertile and rainfed ecosystem

Huge demand for high palatable green fodder for dairy farmers

Dairy is one of the alternative component for economic security of the farmers

\section{SWOT analysis}

The effective implantation of programme needs to assess the following strength, weakness, opportunity and threats in fodder production activity. 


\begin{tabular}{|c|c|c|c|}
\hline Strength & Weakness & Opportunity & Threats \\
\hline $\begin{array}{l}\text { Dairy is one of the } \\
\text { important } \\
\text { alternative } \\
\text { components next to } \\
\text { agriculture for } \\
\text { economic security of } \\
\text { the farmers. }\end{array}$ & $\begin{array}{l}\text { Low productivity due } \\
\text { to local varieties } \\
\text { Lack of knowledge on } \\
\text { fodder production }\end{array}$ & $\begin{array}{l}\text { Lot of scope for high } \\
\text { palatable fodder } \\
\text { production } \\
\text { Dairy is one important } \\
\text { component of the } \\
\text { district }\end{array}$ & $\begin{array}{l}\text { Labour shortage } \\
\text { Scarcity of water } \\
\text { Land requirement }\end{array}$ \\
\hline
\end{tabular}

\section{Interventions of KVK}

Identification of farmers, arranged training programme/capacity building for fodder production and identification of technological gap

Introduction of multi cut fodder sorghum variety COFS-31,

\section{Materials and Methods}

The demonstrations were conducted in Chitradurga district during 2017-18 and 201819 to study the"Extension strategies to popularisation of multicut fodder sorghum var. COFS-31 in Chitradurga district". This study comprised of two plots as demo and check plot and demonstrated in 250 farmer's field with COFS-31 variety. Details of technology demonstrated as below

\section{Preparation of land}

COFS-31 requires a good seed bed with fine tilth of soil for better germination. Preparation of land usually consists of ploughing from three to six times, depending on the type of ploughs used which vary in different parts of the states. The clods are to be broken by harrowing.

\section{Seed rate: $5-6 \mathrm{~kg} / \mathrm{h}$}

A seed of this variety is very small. Hence seeds were mix with fine sand or compost and sown with spacing of $45 \mathrm{~cm}$ from row to row and $10 \mathrm{~cm}$ between the seeds.

\section{Seed treatment}

Use of certified seeds Treat the seeds with Azospirullum (500 g) and phosphate solubilising bacteria $(500 \mathrm{~g})$ per ha will increase yield by 10-15 per cent.

\section{Manures and fertilizers}

Apply 7.5 t/ha of well decomposed farmyard manure or compost at least 2-3 weeks before sowing and incorporate in the soil. Apply 100 $\mathrm{kg}$ nitrogen, $50 \mathrm{~kg} \mathrm{P}_{2} \mathrm{O}_{5}$ and $20 \mathrm{~kg} \mathrm{~K} 2 \mathrm{O}$ per hectare. Half dose of nitrogen and total amount of phosphorus and potash should be applied at the time of sowing. Top dressing 25 $\mathrm{kg}$ nitrogen of two cutting and reaming $25 \mathrm{~kg}$ of nitrogen after fourth cutting.

The technologies was shared to farmers through field day, radio programme, bimonthly, krishi meal and news paper coverage etc.,

Comparison of two fodder varieties i.e. fodder sorghum var. COFS-31 and Napier hybrid bajra $\mathrm{CO}-3$

\section{Extension Strategies Adopted By KVK}

Based on the constraints faced by the farmers and problems identified by KVK, it was 
planned to improved fodder productivity through front line demonstrations in 10 farmer's fields. trainings and organise field days for wider dissemination of the technology

\section{Results and Discussion}

In adoption of any new variety, growth and yield are important criteria to show the performance of giver interventions. The KVK itself took the seed production activities in COFS-31 fodder sorghum variety and produced around $200 \mathrm{~kg}$ seeds and distributed around 1250 farmers in the district. With use of this seeds farmers were able to produced around 4600 tonnes of green fodder. The area under fodder sorghum variety COFS-31 increased from 1 ha to 80 ha and it is alternate crop for fodder Napier hybrid bajra CO-3. The per cent green fodder yield was 25.81 per cent over Napier hybrid bajra CO-3. Reduce dependency on other fodder crops. The large scale adaption this variety mainly due to their high green fodder yields, palatability and drought resistant. The average increase in income of each farmer was 5421 /ha. And also helps to reduce the migration of farmers and rural youth due to encourage of dairy entrepreneurship as one of the important component for economic security of the farmers. During the first year, only five farmers were grown the new fodder sorghum variety COFS-31 variety. After the continuous efforts, enthusiasm and dedication of KVK scientists it spread around 1250 farmers of the district with tune of 12.8 per cent adoption in the district within two years. To create awareness on this variety through conducted twelve on and off campus training programmes during implementation period.

Table.1 Trainings and per cent adoption of technology

\begin{tabular}{|l|c|c|c|c|}
\hline Name of the technology & $\begin{array}{c}\text { No. of farmers } \\
\text { Adopted during first year }\end{array}$ & $\begin{array}{c}\text { No. of farmers } \\
\text { Adopted during second year }\end{array}$ & $\begin{array}{c}\text { Percentage } \\
\text { adaption }\end{array}$ & $\begin{array}{c}\text { No. of training } \\
\text { conducted }\end{array}$ \\
\hline $\begin{array}{l}\text { Introduction of fodder } \\
\text { sorghum var. COFS-31 }\end{array}$ & 5 & 1250 & 12.8 & 12 \\
\hline
\end{tabular}

Table.2 Performance of multicut fodder varieties on growth and yield

\begin{tabular}{|c|c|c|c|c|}
\hline Fodder varieties & $\begin{array}{c}\text { Stem height } \\
(\mathbf{c m})\end{array}$ & $\begin{array}{c}\text { Leaf width } \\
(\mathbf{c m})\end{array}$ & $\begin{array}{c}\text { Stem circumference } \\
(\mathbf{c m})\end{array}$ & $\begin{array}{c}\text { Green fodder } \\
\text { yield }\end{array}$ \\
\hline $\mathbf{T}_{\mathbf{1} \text {-COFS-31 }} \mathbf{C O}$ & 215.6 & 4.5 & 5.4 & 89.6 \\
\hline $\mathbf{T}_{\mathbf{2}-\mathbf{C o}-3}$ & 210.4 & 4.1 & 2.1 & 76.8 \\
\hline SEm \pm & 1.69 & - & & 3.11 \\
\hline CD $(\mathbf{0 . 0 5})$ & 4.92 & - & - & 10.2 \\
\hline
\end{tabular}

Table.3 Attributes and opinion of the farmers about the performance of different multicut fodder varieties

\begin{tabular}{|c|c|c|}
\hline Parameters & COFS-31 & Co-3 \\
\hline Growth & Luxuriant & Moderate \\
\hline Pubescence & Absent & Less \\
\hline Palatability & Good & Moderately \\
\hline Preference & Good & Moderately \\
\hline
\end{tabular}


Table.4 Benefits of the technology

\begin{tabular}{|c|c|c|c|c|c|c|c|}
\hline $\begin{array}{c}\text { Name of the } \\
\text { technology }\end{array}$ & $\begin{array}{c}\text { Palatability } \\
\text { Napier } \\
\text { hybrid } \\
\text { bajra }\end{array}$ & $\begin{array}{c}\text { Palatability } \\
\text { (t/ha) } \\
\text { COFS-31 }\end{array}$ & $\begin{array}{c}\text { Per cent } \\
\text { increase in } \\
\text { palatability }\end{array}$ & $\begin{array}{c}\text { Per cent } \\
\text { increase in } \\
\text { milk yield } \\
\text { after } \\
\text { introduction } \\
\text { COFS-31 }\end{array}$ & $\begin{array}{c}\text { Income } \\
\text { before } \\
\text { introduction } \\
\text { of COFS-31 } \\
\text { (Rs./ha) }\end{array}$ & $\begin{array}{c}\text { Income after } \\
\text { introduction } \\
\text { of COFS-31 } \\
\text { (Rs./ha) }\end{array}$ & $\begin{array}{c}\text { Impact } \\
\text { indicator } \\
\text { (Rs./ha) }\end{array}$ \\
\hline $\begin{array}{c}\text { Introduction } \\
\text { of fodder } \\
\text { sorghum var. }\end{array}$ & 81.1 & 90.4 & 11.5 & 12.4 & 17794 & 23215 & 5421.0 \\
COFS-31 & & & & & & & \\
\hline
\end{tabular}

Fig.1

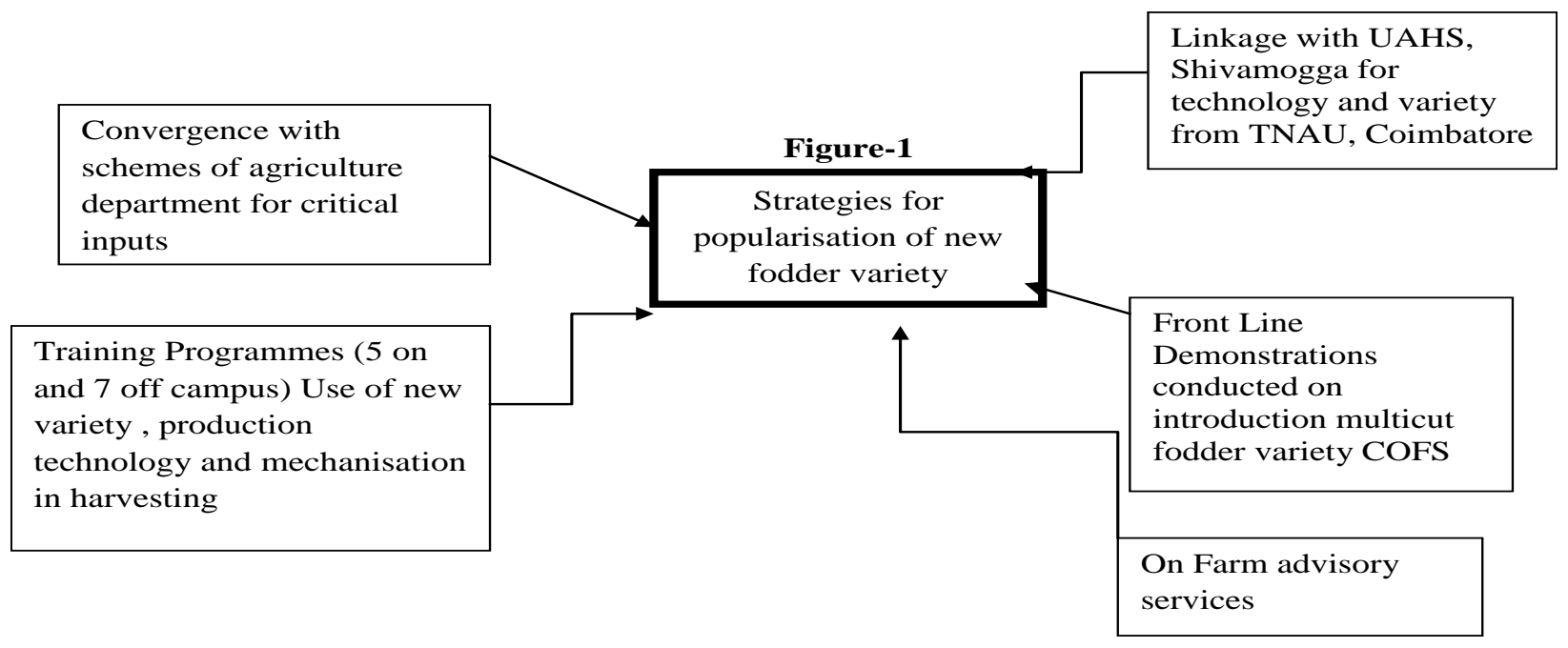

Fig.2 Green fodder yield of the technologies

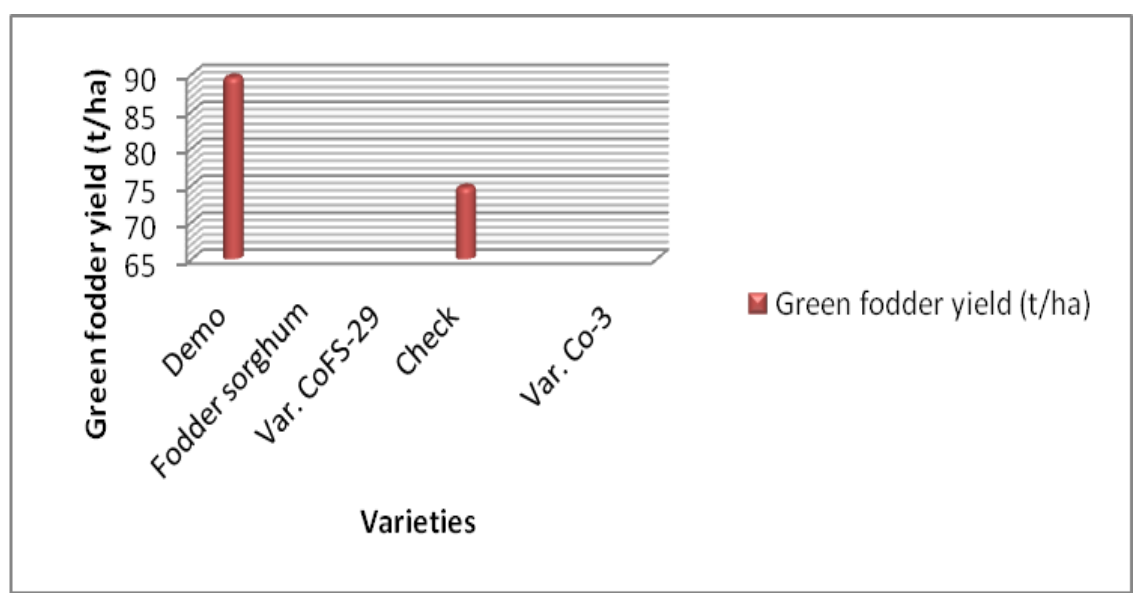


Fig.3 Economics of the technologies

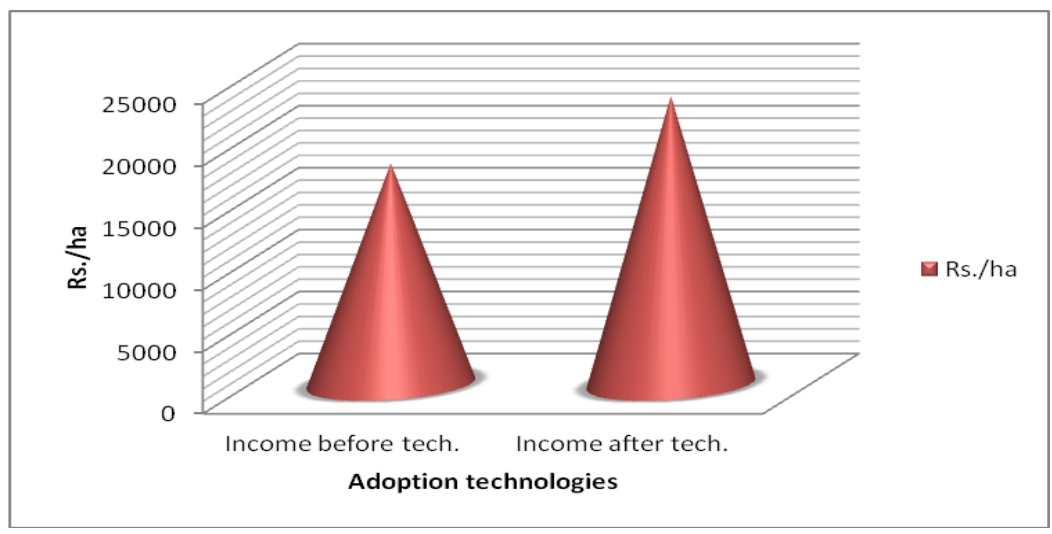

Fig.4 Per cent palatability of technology

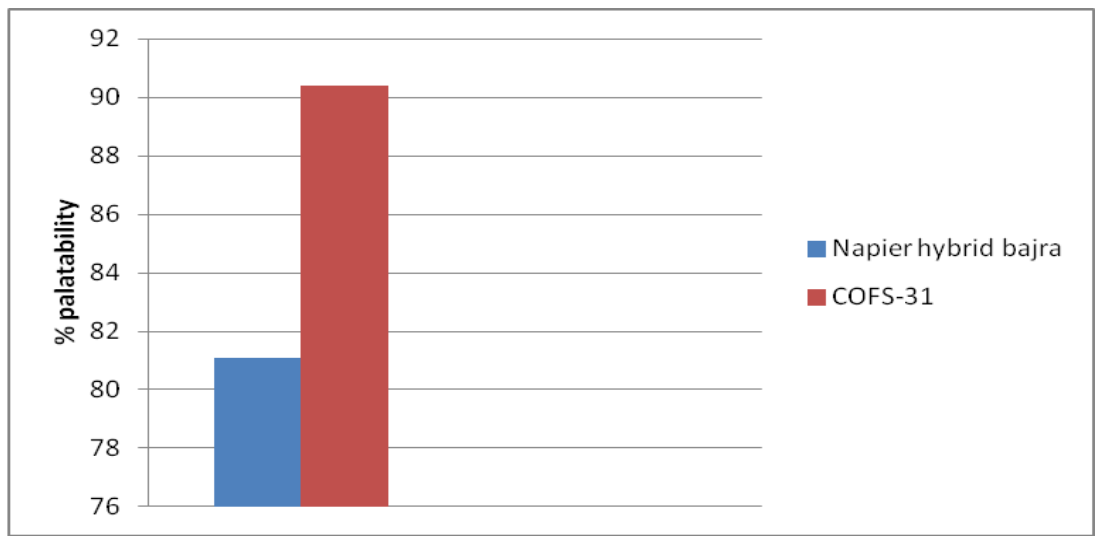

The results of two years pooled data revealed that among the two fodder varieties, fodder sorghum variety COFS-31 recorded significantly higher stem height $(215.6 \mathrm{~cm})$, leaf width $(4.5 \mathrm{~cm})$ and green fodder yield $(89.6 \mathrm{t} / \mathrm{ha})$ and lower stem girth $(3.2 \mathrm{~cm})$ over Napier hybrid bajra (210.4, 4.1, 5.4 and 74.7 $\mathrm{t} / \mathrm{ha}$, respectively) which is higher by $19.9 \mathrm{per}$ cent (Kamal Bai et al., 2017). The higher palatability per cent was recorded in COFS $31(90.4 \%)$ over Napier hybrid bajra (81.8 $\%$ ) with tune of 11.5 per cent (K Sai Maheswari et al., 2019). The income before and after adaption of this technology were Rs. 17794 /ha and 23215, respectively. The impact indicator of this technology was Rs. 5421 /ha. Farmers optioned that COFS-31 have luxuriant growth, less pubescence, high palatability.

\section{Cases of large adoption}

Implementation of KVK programme has resulted in cases of large adoption by the farmers in respect new variety COFS-31. Due to continuous persuasion by the scientists of KVK during conduct of FLD and trainings related to introduction of new variety and improved fodder production technology.

In conclusion thus, introduction of new variety COFS-31 with improved production technologies from front line demonstrations, method demonstration, trainings, news paper and radio through KVK interventions has been found more productive and profitable as compared to farmer's practice. This technology is spread in the district and farmers are convinced about the technology. 


\section{References}

Anonymous, 1999, Economic Survey1998-

99, Government of Karnataka, Bangalore.

Anonymous, 2016, Chitradurga District at Glance, 2014-15, District statistical Officer, Chitradurga.

Kamala Bai et al., 2017, Performance of dissemination of multicut fodder crops in Ramanagar District, Karnataka state, India. International Journal of Current Microbiology and Applied Science, 6(10): 4918-4923.

Sai Maheswari, K, T Prathima, D Subramanyam and P Latha., 2019, Performance of fodder sorghum varieties under varied times of sowing in summer, International Journal of Chemical studies, 7(3): 3404-3406.

\section{How to cite this article:}

Rudragouda F. Channagouda, S. Onkarappa, Prakash Kerure, Jyoti and Rudramuni, T. 2020. Extension Strategies to Popularisation of Multicut Fodder Sorghum var. COFS-31 in Chitradurga District, Karnataka State, India. Int.J.Curr.Microbiol.App.Sci. 9(11): 342-348. doi: https://doi.org/10.20546/ijcmas.2020.911.041 